\title{
Consistency Implementation of the Regulation on Young Marriage in Indonesia
}

\section{Darmadi}

${ }^{1}$ Law Faculty, Universitas 17 Agustus 1945 Banyuwangi, East Java, Indonesia

*darmadi301956@gmail.com

\begin{tabular}{|c|c|}
\hline Article & Abstract \\
\hline $\begin{array}{l}\text { Article History } \\
\text { Received: Augt 8, 2020; } \\
\text { Reviewed: Augt 13, 2020; } \\
\text { Accepted: Sept 15, 2020; } \\
\text { Published: Sept 30, } 2020\end{array}$ & $\begin{array}{l}\text { The amendment of Law Number } 1 \text { of } 1974 \text { to Law Number } 16 \text { of } 2019 \\
\text { concerning Marriage, especially Article } 7 \text { paragraph (1) concerning the age of } \\
\text { marriage for the prospective bride, is equal to the age of the prospective groom, which } \\
\text { is } 19 \text { years. Meanwhile, young age is that the prospective brides are still under } 19 \\
\text { years old. This has indeed been required by the legislators so that the prospective } \\
\text { bride and groom have a mature mindset and do not easily marry and divorce in } \\
\text { married life but in reality what happens in society can cause new problems, namely } \\
\text { the prospective bride and groom together. The objectives of this study were to find } \\
\text { out the consistency of the application of article } 7 \text { of Law Number } 16 \text { of } 2019 \text {, } \\
\text { amendments to Law Number } 1 \text { of } 1974 \text { regarding the incidence of marriage at a } \\
\text { young age, and to determine the impact of marriage at a young age and some of the } \\
\text { problems that accompany it. The method of this study was the Juridical Empirical } \\
\text { method or sociological research. This research was carried out either through } \\
\text { observation and interviews in the form of a Religious Court Decision Letter } \\
\text { regarding marriage permits. This was done and demonstrated through data in the } \\
\text { field, the point of an empirical approach as a social-cultural reality. The result of } \\
\text { this research showed that the consistency of the application of article } 7 \text { paragraph } \\
1 \text { regarding the age limit in marriage as stipulated in Law Number } 16 \text { of } 2019 \\
\text { as a result of the Amendment of Law Number } 1 \text { of } 1974 \text { concerning Marriage } \\
\text { was still not fully implemented. It was proven that there were still many people who } \\
\text { not yet aware of the consequences of young marriage. The impact of young marriage } \\
\text { was very large from various points of view. }\end{array}$ \\
\hline
\end{tabular}

(C2020; This is an Open Acces Research distributed under the term of the Creative Commons Attribution Licencee (https://Creativecommons.org/licences/by/4.0), which permits unrestricted use, distribution, and reproduction in any medium, provided the original works is properly cited.

\section{INTRODUCTION}

The marriage law in force in Indonesia is fundamental to the provisions of Law Number 16 of 2019 as a result of the amendment of Law Number 1 of 1974, which article (1) states that "marriage is a physical and mental bond between a man and a 
woman as husband and wife. to form a happy and eternal family (household) based on the One Godhead ". For a country and a nation like Indonesia, it is necessary to have a National Marriage Law which at the same time accommodates the principles and provides a legal basis for marriage which has been the guide and has been applied to various groups in our society (Sudarsono, 2010).

True marital happiness is needed by a husband and wife who are compatible both physically and spiritually from both parties, there is always an agreement of will and always need both people to make a marriage that works well and is full of struggles to overcome all difficulties that interfere with the harmony of the peace of the houseladder, especially because the negligence of one party only to care for themselves will certainly result in the breakup of their marriage (Lestari, 2015).

In establishing a household is an interest for all people who are young at heart. Lots of new things will be seen and done based on joyful experiences to be enjoyed together and the most enjoyable of all is the order of life that helps each other, has a mutual understanding of living together, joys and sorrows together in solving all forms of problems in the home stairs (Burchinal, 1960). Likewise, on the other hand, there are no problems that cause disappointment for one of the parties, both wife and husband, if the thing concerned does not want to be aware of it, it will fail in navigating through domestic life. Thus for people, both men, and women who are still not ready, the way of thinking about getting married is better not to get married first, because it will lead to failure in their household (Muslihatun \& Djanah, 2018).

A prospective husband or wife needs to make up their minds before they enter into marriage and this is a recommendation from Law No.1 of 1974 so that the marriage will be permanent, this is following the purpose of marriage, namely to form a happy and eternal household. however, in reality, in the field, most of them do not match what is expected together. Although Law Number 1 of 1974, especially Article 7 provides a minimum age limit requirement, this is still not fully complied with due to the influence of the situation and conditions of each prospective bride, for example, the person concerned is only 15 (fifteen years old but the condition is already pregnant, while article 7 (seven) paragraph 1 of Law Number 1 of 1974 states that "Marriage is only permitted if the male has reached the age of 19 (nineteen) years and the woman has reached the age of 16 (sixteen) years" and paragraph 2 (two) reads "In case of deviations from paragraph 1 (one) of this article, dispensation may be requested from the court or other official appointed by the parents of both the male and female parties." With the basic provisions of Article 7 (seven) paragraph (1) and (2) said the prospective bride and groom, both male and female candidates, still have not reached the age stipulated by law. the implementation of the marriage is tolerated, it's just that 
the result of the marriage will certainly result in various problems caused by it, especially those that are not by the purpose of the marriage itself, namely to form a happy household physically and mentally as mentioned in article 1 of Law Number 1 of 1974 concerning Marriage which, among other things, states "That marriage is a physical and spiritual bond between a man and a woman as husband and wife to form a family (household) that is happy and eternal based on the One God". Thus, if we look at the meaning of marriage, it is a sacred bond or a sacred act and cannot be underestimated because both husband and wife have a great sense of responsibility, both fellow humans and with Almighty God.

As a country based on Pancasila, where the first precept is the Supreme Lordship, marriage has a very close relationship with religion/spirituality, but the inner/spiritual element also has an important role, forming a happy family, closely related to offspring, maintenance. and children's education is the obligation of parents to be the goal of marriage (Sugiarto, 2013). Marriage Law Number 1 of 1974 article 1 states that "Marriage is a physical and spiritual bond between a man and a woman as husband and wife to form a happy and eternal family (household) based on God Almighty". Thus it can be said that marriage is a holy act because it has a very strong relationship with religion and spirituality.

A marriage when viewed from customary law, that marriage is a very important event in the order of social life, because marriage does not only involve the relationship of a man and woman as a prospective bride but also the parents of both parties, their siblings, even their respective families, even the marriage is an important event for those who are still alive but the marriage is also a very meaningful event that fully gets the attention and is followed by the spirits of the ancestors from both sides. From these spirits, both parties and their entire family also hope for their blessing for the bride and groom, so that after marriage they can live in harmony as husband and wife based on God Almighty.

Therefore marriage has such an important meaning, then its implementation always starts onwards accompanied by various kinds of ceremonies even equipped with offerings that are said to beg for the blessing of the ancestral spirits of their respective families. This may all be called superstition, but in reality, until now these things are still very pervasive to the trust of the majority of the Indonesian people and therefore are still being carried out everywhere.

Prof. Hazairin in his book entitled 'Rejang', describes the marriage incident as a series of three series of magical acts that aim to ensure peace, happiness, and fertility of each so that offspring are quickly given because one of the goals of marriage is to 
develop offspring. Likewise, A. Van Gennep, a French sociologist, called all the wedding ceremonies the "rites de pasaage" (transitional ceremonies), which is a transitional ceremony that symbolizes the transition and change of status of the bride and groom who had lived separately, after carrying out the ceremony. marriage is meant to finally live together in life together as husband and wife (Wignjodipuro, 2017).

Marriage according to Western Civil Law, is a legal relationship between a man and a woman for a long time. The Civil Law considers that marriage is only from a civil relationship. Thus article 26 BW. (Burgerlijke Wetboek) in viewing this article states that legal "marriages" are only marriages that only meet the requirements or conditions set out in the Civil Code, and religious terms and regulations are set aside, such as the implementation of polygamy is prohibited for the sake of public order ((Subekti, 2010). This is very different from what is stipulated by Law Number 1 of 1974, which article 2 (two) states that " marriage is legal if it is carried out according to one's respective religion".

The exercise of rights and obligations is often a source of disputes because the exercise of rights is excessive or does not fulfill obligations that can cause harm to other parties. Members of society who are still unfamiliar with the purposes and objectives of Law Number 1 of 1974 concerning marriage can become victims of the practices carried out by those who are solely looking for personal gain and the satisfaction of their desires. Such is the case with temporary marriages that are not following the aims and objectives of the marriage that is a happy and eternal family.

Marriages that are temporary as they are now commonly referred to as "contract marriages" or "season marriages", that is, if a person is only there while he is in that place and when his contract expires, then his wife is just left without any responsibility as a husband. together without being tied in the marriage rope that has been determined by the law on marriage is not justified, because it can harm all parties, both husband and wife as well as the children born from the marriage. This is not following regulations and religion.

Living together can cause difficulties which include the following:

1. It is difficult to determine the status of the woman or man in question whether this man or woman is considered to be married or married.

2. It is difficult to determine the status of a child born in this coexistence and it will also cause difficulties for feelings as a child outside of marriage that always presses his heart.

3. Encourage a kind of polygamy/polyandry because it is not recorded in the marriage registration book. 
4. It is difficult to determine inheritance rights for such children if their father does not recognize them as their children.

Therefore, the issuance of Law Number 1 of 1974 concerning marriage is an effort so that people can understand and live, and it is hoped that they can carry out their experiences following their aims and objectives. The young age of marriage that is meant here is about the age limit of both the prospective groom and the prospective bride who will marry must have reached the age of 19 years for the prospective groom and have reached the age of 16 years. for the prospective bride, Clause 7 paragraph (1). From the provisions of this article, it can be explained that if the bride and groom are of such age, of course, they are already considered to have a mature thought or understand their respective rights and responsibilities. However, this method is very objective and difficult, so that is why in determining one's competence, but from an objective point of view, it is easier to prove. The problem now is at what age a child is considered competent, of course, it cannot be generalized, but it depends on the problems it faces (Febrina, 2018; Latifiani, 2019).

To determine the issue of status as a subject in marriage using legal measures or provisions (yuridiche handelnge onbekwam heid) as a guideline can be seen in article 47 of Law Number 1 of 1974 which among other things states that paragraph 1: children who have not reached the age of 18 years or have never been married under the control of their parents as long as they are not removed from power (Anwar \& Rahmah, 2016).

Likewise, according to the provisions of article 330 of the Civil Code which states that it is not yet mature for those who have not reached the age of 21 years, and or have not been married beforehand. If the marriage is dissolved before the age of 21, they will not return to their status as immature. For those who are not yet mature and not under the control of their parents, they are under guardianship on the basis and in the manner set out in the third, fourth, fifth, and sixth sections of this chapter (Subekti, 2010).

Based on the aforementioned information that is what is meant by the marriage age limit that is listed in article 7 paragraph 1 of Law Number 1 of 1974 concerning Marriage is the lowest limit for implementing marriages even though in essence it is legal according to the law. Then, as it is said, "Underage marriages are marriages that are carried out with an age limit below those in the provisions of the law, namely if the male is still under the age of 19 years and for women is under the age of 16 years. Likewise, on the other hand, "adult marriages" are marriages that are carried out with a size or age limit above the size stipulated by law, namely being over the age of 19 years for men and over 16 years for girls. 
Based on these problems, this research was conducted to find out the consistency of the implementation of Article 7 of Law Number 16 of 2019 as a result of the amendment of Law Number 1 of 1974 regarding the incidence of marriage at a young age and to find out the impact of marriage at a young age and some of the problems that accompany it

\section{METHOD}

This research used juridical empirical research methods or sociological research which means research that emphasizes the reality or facts in the field (Fajar \& Achmad, 2013). Empirical research is research that is obtained directly from resource persons as the first source through field research which is carried out either through observation and interviews, in the form of a Religious Court Decree regarding marriage permits. This was done and demonstrated through data in the field, the point of an empirical approach as a socio-cultural reality because in this study it focuses on the amendment of article 7 of Law Number 1 of 1974 which was amended to Law Number 16 of 2019 concerning Marriage.

After Law Number 1 Year 1974 was amended to Law Number 16 Year 2019 Concerning Marriage, Article 7 regulated by Law Number 1 Year 1974 was declared invalid. This is following statutory principles that read "the existing law then negates the previous law". Judging from the nature and objectives of empirical research, the author uses a qalitative descriptive approach, meaning that research aims to describe systematically, accurate facts and characteristics about the population regarding a particular field, namely to describe and explain the data found in the study, this is in line with what is stated. According to Sugyono's opinion (2010: p. 80), among others, states that the interview is a process of interaction and communication between the interviewer and the resource person by way of direct questioning and carried out directly, in line with the thought of the author who has visited several Religious Affairs Offices of the Banyuwangi Religious Court so that the authors get the required data.

The legal materials that will be used as data sources include the following primary data, secondary data, and tertiary data. Primary data is obtained directly from the results of field research, namely visiting those who have carried out a marriage even though their age is still below the age specified by the marriage law, namely through observation, interviews, and data collection related to the problem under study. Secondary data is used to supplement primary data sources in the form of legislation, books, journals, articles, documents, internet sources, and other sources that are related to the problem under study. The laws and regulations used in this research are Law Number 1 of 1974 concerning Marriage (Badan Penasehat Perkawinan Perselisihan dan Perceraian (BP4), 1983), Law Number 17 of 2016 concerning Stipulation of Government Regulations in place of Law Number 1 of 2016 Concerning the Second Amendment to Law Number 23 of 2002 About Child Protection (Presiden Republik Indonesia, 2016). Tertiary data sources, namely data sources that provide guidance and 
explanation of primary and secondary legal materials, such as legal dictionaries, Indonesian and English dictionaries. Besides, the authors also use non-legal materials that are considered relevant to this study.

All data obtained from primary, secondary, and tertiary data were then analyzed using qualitative techniques, the nature of the analysis was descriptive-analytical and used deductive reasoning. Data analysis is an activity in research in the form of conducting a study or review of processing results and that is assisted by theories that have been previously obtained. In simple terms, data analysis is referred to as member review activity which can mean opposing criticism, supporting, adding or commenting, and then making a conclusion to the research results with one's thoughts and the help of theories that have been mastered (Fajar \& Achmad, 2013).

\section{RESULTS AND DISCUSSION}

\section{Marriage Conditions According to Law No. 1 of 1974}

Marriage is a legal act between a man and a woman to form a family based on applicable regulations so that after the marriage takes place, a family law relationship (familierecht) emerges, which emphasizes Law Number 1 of 1974 concerning Marriage, considering The law revokes the enactment of provisions concerning marriage and all its legal consequences contained in the Civil Code (Prakoso, 2018).

Based on the provisions of article 6 paragraph (1) of Law Number 1 of 1974 concerning Marriage, it states that the marriage must be based on the agreement of the two brides. To get married a person who has not reached the age of 21 (twenty-one) years must obtain permission from both parents (article 6 paragraph (2). In case one of the parents has died or is unable to declare his will, then the permission referred to in paragraph (2) of this article is sufficient to obtain from parents who are still alive or from people who can express their will (article 6 paragraph (3). If both parents have passed away or are unable to express their will, the permission obtained from guardians, people who care for or their families who have blood relations in a straight line up as long as they are still alive and in a state can map out his will (article 6 paragraph (4). In case there are differences of opinion between the people mentioned in paragraph (2), paragraph (3) and paragraph (4) of this article, or one or more of them cannot declare their will, the court in the jurisdiction At the request of the person, the resident who is to enter into the marriage can give permission, after hearing the persons mentioned in paragraph 2, paragraph 3, and paragraph 4 of this article (article 6 paragraph (5)).

The provisions in paragraph (1) to paragraph (5) of this Clause shall apply as long as the law of each religion and belief does not specify otherwise (Clause 6 paragraph (6).

\section{Consistency of Marriage Age Limits}


The entry into force of Law Number 16 of 2019 concerning Marriage, to be precise on 15 October 2019, mainly in the provisions of Article 7 paragraph (1) which states that "marriage is only permitted if a man and woman have reached the age of 19 (nineteen) years". This condition causes many parents to apply for their children as prospective brides who ask for permission to be able to carry out marriage, from the information obtained by the authors of interviews from various parties such as with several Heads of the Office of Religious Affairs and Chair of the Religious Courts through employees or employees who have been appointed to provide information to the author. The results of the interview can be explained in general, including the following:

1. Determination of the Religious Court Number: 0565 / Pdt.P / 2020 / PA.Bwi who was proposed by Pak Surateman bin Ponirin to apply for a marriage permit for his son named: Via Nur Mahampang bin Surateman who was born on March 17, 2003, is now 17 (seventeen) years old who will marry a man named Riko Setiawan bin Sumadi, now 18 (eighteen) years old, with a Decree dated 30 June 2020.

2. Determination of the Religious Court Number: 0564 / Pdt.P / 2020 / PA.Bwi proposed by Sumadi bin Sampir to permit marriage in the name of his son named Via Nur Mahampang bin Surateman as the future wife of Rico Setiawan bin Sumadi and now 17 years old, with a Decision Letter dated 30 June 2020.

3. Determination of the Religious Courts Number: 0617 / Pdt.P / 2020 / PA.Bwi. The one proposed by Samsul Hadi bin Mahfud, regarding the permission of marriage in the name of his son named: Nabila Aprilia Ningsih binti Zaenal Arifin aged 14 (fourteen) years 2 (two) months as the future wife of Deva Nyiar Ari Sandria bin Sudarmadi aged 14 (fourteen) ) year 7 (seven) months, with a Letter of Determination on July 14, 2020.

4. Determination of the Religious Court Number: 0618 / Pdt.P / 2020 / PA.Bwi. proposed by Sudarmadi bin Samuji regarding permission to marry in the name of his son named: Deva Nyiar Sandria bin Sudarmadi aged 14 (fourteen) years 7 (seven) months, November 20, 2005, as the future husband of Nabila Aprilia Ningsih binti Zaenal Arifin aged 14 ( fourteen) years and 2 (two) months.

5. Pernetapan Religious Court Number: 0393 / Pdt.P / 2020 / PA.Bwi proposed by Yuel Sugiyono bin Kurmen on behalf of his biological child named: Ayu Fita Diansari binti Yuel Sugiyono aged 15 (fifteen) years (birth date 25 June 2004) and has the status of a girl who has never been married with the Decision Letter of April 13, 2020.

Some of the examples mentioned above were evidence of the results of the author's interview with Mr. Mohamad Arif Fauzi, SHi., MH. As the Junior Registrar of the Application, the Banyuwangi Religious Court which the author conducted on Monday, July 202020 as well as the author also interviewed with Substitute Bailiff named Mohamad Jidni, SH., which the author did on Thursday, July 23, 2020. He explained that the example was only a small part, then he said that the submission of a request for permission or recommendation from the Religious Court only and this still has not been sourced from the State Court, to carry out a marriage, in fact, every 
day on average can reach about 20 (twenty) people and the sample was only in one Purwoharjo sub-district. The author interviewed Mr. Lukman Hariyanto, S.Hi as Head of the Office of Religious Affairs in one of Purwoharjo Districts and the author did it on Wednesday, 29 July 2020, as in the example mentioned above, of course, there must be other subdistricts too.

Employees who register marriages are not allowed to carry out marriages in violation of the regulations contained in Law Number 1 of 1974 concerning Marriage. This is expressly regulated in the provisions of Article 21 of the marriage law which states that if a marriage registrar believes that the marriage is prohibited according to this law, then he will refuse to enter into a marriage. In the case of rejection, the request of one of the parties wishing to marry by the marriage registrar will be given a written statement of the refusal accompanied by the reasons for the refusal.

The parties whose marriage has been rejected have the right to submit an application to the court in the area where the marriage registrar who holds the refusal is domiciled to give a decision by submitting the statement of rejection mentioned above. The court will briefly examine the case and will provide a decision as to whether he will uphold the refusal or order the marriage to take place. This determination loses its strength if the obstacles that result in the rejection are lost and the parties who wish to be able to repeat the notification of their intentions (Sugiarto, 2013).

\section{The Impact of Marriage at a Young Age}

As has been explained in the previous chapters that marriage at a young age is a marriage which is carried out with an age limit below that in the statutory provisions, that is if a man is under the age of 19 and for a woman he is below the age limit 16 years old (Fadlyana \& Larasaty, 2016). Prohibitions have been carried out but from the awareness of the community itself that they cannot understand it so that in reality there are still some who carry out unregistered marriages, contract marriages that are leased by agreement, and so on (Muslihatun \& Djanah, 2018). If some dare to do this, it will have an impact on both parties, including the following:

\section{Age of marriage in terms of Islam}

Islam has recommended that someone who can bear the burden of the family should be able to immediately get married. Because marriage will always bring peace of mind and the ability to maintain a sense of humility from abuse and whoever doesn't have the ability, let you fast first, that fasting will be a fortress that will protect him from all wrongdoing (Oebaya, 1980).

Islam also justifies the existence of an effort and effort to postpone those who are not yet capable and for those who are unable to marry, they should maintain (themselves) purity, so that Allah enables them with their Grace. From the aforementioned explanation we can conclude that what can be justified in Islam is to 
avoid the occurrence of pregnancies, especially pregnancies at a young age which are meaningful and are:

a. To maintain the safety of the soul or health of mother and child.

b. To maintain religious safety, parents are burdened with the obligation to meet the needs of their families and children

c. To maintain the safety of the soul, health, or education of their children.

Therefore, in Islam at adulthood or when it has arrived at the time the child should be endeavored to marry as a normal human nature and to follow the Sunnah of the Prophet Muhammad SAW to form a happy and prosperous household and family. If the household is neatly organized, filled with tranquility, love and affection will certainly be able to enhance the quality or value of life and livelihood in society, and which means it can strengthen the development of a country that is strong, just and prosperous, peaceful, happy and prosperous (Oebaya, 1980).

\section{Age of marriage in terms of health}

The Minister of Health appealed to all Indonesian people to increase "Marriage age" among the community is a matter of education for the people to have awareness and understand the importance of increasing marital age if viewed from health, population, and welfare of life, marriage at a young age is unfavorable for all parties. So that the program to increase the age of marriage can be interpreted as an effort to invite the community, especially the younger generation, to carry out marriages until they are of the right and healthy age (Rahmah \& Anwar, 2015).

Some of the bad consequences that occur because the marriage is too young and even still have not reached the age of the marriage limit that has been determined by applicable legislation (Bastomi, 2016). From a health point of view, there are obstacles to pregnancy and childbirth, including:

a. There is bleeding during childbirth;

b. The labor process is long due to physical weakness due to young age;

c. Difficult delivery due to narrow hips;

d. Susceptible to cervical cancer in the future;

e. And so on (Oebaya, 1980).

\section{Age of marriage in terms of Social Psychology (Psychology)}

It is important to know that the function of personality is not always fixed, it always changes according to certain phases of development. In certain phases/stages of age, people generally have certain personality traits too. Changes in personality development from one phase to the next, arising mental shock of the individual concerned is only temporary. the return of mental stability can be quick or slow to achieve depending on the good and bad of one's adaptation function. This mental shock is at its peak when there is a personality change to the "puberty" phase, which is why this phase is considered a critical period for humans and is certainly not good for tying the knot at this time (Ridzuan et al., 2018). 
From the aforementioned description, it is clear that the age factor has a big influence on the development of personality towards instincts which of course will further affect the marriage rope. Generally, most people think that the age of the teenager is between the ages of 12 to 20 years, but many also do not agree with the age limit. They consider puberty as a transition period from childhood (schooling) to adulthood, this means that they are completely dependent on their parents for independent efforts (Susanti, 2019).

In a village, puberty may only reach the age of 14 , because at that age the individual can become independent as a farm laborer (Meiandayati, Nirmala, Didah, \& Susanti, 2018). In contrast to urban communities, on the other hand, puberty can be prolonged until the age of 25 years or even 30 years, because at that age individuals are still dependent on their parents as students. This transitional period is what makes it difficult for young people to adjust to their parents and society. They live full of doubts, they are struggling to find and understand themselves. We cannot expect consistent results from them, because they need more help and guidance (Addilah \& Ummu Siti, 2014). His desire to detach himself from his parents and his inability to stand up completely caused a resentful protest against the parental ties, apart from being tense, easily distracted, and easily aroused by revolutionary influences. This kind of personality, of course, puberty is not suitable for tying a marriage. With good adaptability, normal individuals wish to find their personality after learning from experience and immediately prepare themselves to enter into an adult personality full of calmness, stability, and responsibility (Lestari, 2015).

From the description above, it is clear that the age of marriage that is not good is the age of puberty between the ages of 12 (twelve) to 20 (twenty) years, while the good ones are those who are adults, namely between the ages of 20 (two). thirty) up to 30 (thirty) years (Oebaya, 1980).

\section{CONCLUSION}

The government that has programmed family planning according to the author is very precise because in fostering, nurturing, and financing education the number of children that is a little cheaper when compared to financing a large number of children will certainly incur more costs as well. This is very much following the purpose of marriage which is regulated by Law Number 1 of 1974 concerning Marriage, namely to form a happy and prosperous family. Thus, this scientific paper will give a conclusion, among others:

1. The consistency of age restrictions in a marriage that has been stipulated in Law Number 1 of 1974, especially Article 7 paragraph (1) and paragraph (2) is still not fully implemented, because it is evident that in reality there are still many people who do not realize the importance of the consequences of marriage. which is carried out at a young age and marriages of "siri", contract marriages especially rural people who have a higher percentage than urban people. So there are still many violations committed by the community, while the sanctions for violating article 7 paragraph (1) and paragraph (2) of Law Number 1 of 1974 concerning Marriage are still less strict. 
2. The effects of young marriages are enormous when viewed from various perspectives, as the authors discussed in detail in the previous chapters. Thus, the government through the National Family Planning Coordination Agency recommends the community to increase the age of marriage to invite the younger generation, especially to delay their marriage until adulthood first so that it is appropriate and healthy, following the purpose of marriage, namely forming a family that is happy, eternal and prosperous based on the One God.

\section{REFERENCES}

Addilah, \& Ummu Siti. (2014). Implikasi Hukum Dari Perkawinan Siri Terhadap Perempuan dan Ana. Implikasi Hukum Dari Perkawinan Siri Terbadap Perempuan Dan Anak, 7(1), 1-30.

Anwar, Z., \& Rahmah, M. (2016). Psikoedukasi Tentang Risiko Perkawinan Usia Muda untuk Menurunkan Intensi Pernikahan Dini pada Remaja. Psikologia: Jurnal Psikologi, 1(1), 1. https://doi.org/10.21070/psikologia.v1i1.749

Badan Penasehat Perkawinan Perselisihan dan Perceraian (BP4). (1983). UndangUndang No. 1 Tabun 1974 Tentang Perkawinan Serta Peraturan Pemerintah No. 9 Tahun 1975. Jakarta.

Bastomi, H. (2016). Pernikahan Dini Dan Dampaknya (Tinjauan Batas Umur Perkawinan Menurut Hukum Islam Dan Hukum Perkawinan Indonesia). Jurnal Pemikiran Dan Penelitian Sosial Keagamaan, 7(2), 354-384. https://doi.org/http://dx.doi.org/10.21043/yudisia.v7i2.2160

Burchinal, L. G. (1960). Research on Young Marriage: Implications for Family Life Education. The Family Life Coordinator, 9(1/2), 6. https://doi.org/10.2307/581494

Fadlyana, E., \& Larasaty, S. (2016). Pernikahan Usia Dini dan Permasalahannya. Sari Pediatri, 11(2), 136. https:// doi.org/10.14238/sp11.2.2009.136-41

Fajar, M., \& Achmad, Y. (2013). Dualisme Penelitian Hukum Normatif \& Empiris. Yogyakarta: Pustaka Pelajar.

Febrina, N. (2018). Pernikahan Dini dan Dampaknya. Jurnal Living Hadis, 3(1), 47-70. https://doi.org/https://doi.org/10.14421/livinghadis.2017.1362

Latifiani, D. (2019). The Darkest Phase For Family: Child Marriage Prevention and Its Complexity In Indonesia. Journal of Indonesian Legal Studies (IILS), 4(2), 241258. https://doi.org/https://doi.org/10.15294/jils.v4i2.34708

Lestari, R. P. (2015). Hubungan Antara Pernikahan Usia Remaja Dengan Ketahanan Keluarga. JKKP (Jurnal Kesejabteraan Keluarga Dan Pendidikan), 2(2), 18. https://doi.org/10.21009/jkkp.022.04

Meiandayati, R., Nirmala, S. A., Didah, D., \& Susanti, A. I. (2018). Kejadian Pernikahan Usia Dini Berdasarkan Karakteristik Dan Sosial Budaya Di Desa Cipacing Kecamatan Jatinangor Kabupaten Sumedang Tahun 2014. Jurnal Sistem 
Kesehatan, 1(2), 76-83. https://doi.org/10.24198/jsk.v1i2.18129

Muslihatun, W. N., \& Djanah, N. (2018). The Marriage Age Maturity Program and The Age of Marriage Olan in Teenage Girl. Jurnal Kesehatan Ibu Dan Anak, 12(2), 100-106. https://doi.org/10.29238/kia.v12i2.157

Oebaya, F. (1980). Pandangan agama Islam terbadap keluarga berencana. Jakarta: Badan Koordinasi Keluarga Berencana Nasional.

Prakoso, A. (2018). Pengantar Hukum Indonesia. Yogyakarta: Laksbang Presindo.

Presiden Republik Indonesia. Undang-Undang Republik Indonesia Nomor 17 Tabun 2016. , (2016).

Rahmah, M., \& Anwar, Z. (2015). Psikoedukasi Tentang Risiko Perkawinan Usia Muda Untuk Menurukan Intensi Pernikahan Dini Pada Remaja. Jurnal Intervensi Psikologi (JIP), 7(2), 158-172.

https://doi.org/10.20885/intervensipsikologi.vol7.iss2.art3

Ridzuan, A. R., Alam, S. N. S., Ridzuan, A. R., Nazri, N. M., Abdullah, M. H. T., \& Ismail, I. (2018). Factors of Disapproving of Early Marriage in Malaysia. International Journal of Academic Research in Business and Social Sciences, 8(10), 915926. https://doi.org/10.6007/ijarbss/v8-i10/4789

Subekti. (2010). Pokok-Pokok Hukum Perdata. Jakarta: P'T. Intermasa.

Sudarsono. (2010). Hukum Perkawinan Nasional. Jakarta: Rineka Cipta.

Sugiarto, U. S. (2013). Pengantar Hukum Indonesia. Jakarta Timur: Sinar Grafika.

Susanti, E. (2019). Unequal gender relations in the practices of girl marriage in poor families at East Java Province. Masyarakat, Kebudayaan Dan Politik, 31(4), 440. https://doi.org/10.20473/mkp.v31i42018.440-450

Wignjodipuro, S. (2017). Pengantar Dan Asas-Asas Hukum Adat. Jakarta: Gunung Agung. 